\title{
AKTIVITAS ANTIFOULING Avicennia marina TERHADAP MACROFOULER Perna viridis
}

\author{
Gannisa Alfin Cahyaningtyas $^{\mathrm{a} *}$, Feni Iranawati ${ }^{\mathrm{a},}$, Citra Satrya Utama Dewi ${ }^{\mathrm{a}}$ \\ ${ }^{a}$ Program Studi Ilmu Kelautan \\ Fakultas Perikanan dan Ilmu Kelautan, Universitas Brawijaya \\ Jalan Veteran, Malang, Indonesia
}

\begin{abstract}
Fouling can be defined as undesired aggregation of living organism on float or submerged thing (ships, wharf, and the others off shore building). Fouling may effect on the function and maintenance of an object by lessen their lifetime, and evoked invasive species. TBT antifouling materials such as in paint widely used to prevent fouling organism, but this substance gave negative impact on the environment. It not only wipes out fouling organism but also other organism and some degree cause imposex. Therefore in 2008, the use of this antifouling was banned by International Maritime Organization. This research aiming to found potential marine natural product there are mangrove as antifouling. This research was conducted on September to December 2016. The experimental design for this research was using completely randomized design. Result shows that experimental the extract of Avicennia marina did not have significant impact on Perna viridis ability to bind onto subtrate. Nevertheless, A. marina had impact on P. Viridis byssus production. Lesser number and shorter length of byssus was yield from the treatment concentration compared to the control. This research indicated that Avicennia marina may have antifouling potential, but further study is needed.
\end{abstract}

Keywords: Antifouling, Avicennia marina, Byssus, Perna viridis

\section{Pendahuluan}

Marine fouling merupakan aktivitas penempelan organisme laut pada benda-benda yang mengapung atau terendam di perairan seperti kapal, dermaga, dan bangunan lepas pantai. Dampak yang ditimbulkan adalah berkurangnya masa pakai benda yang ditempeli organisme fouler. Selain itu berpotensi terjadi penyebaran spesies asing [1]. Untuk menanggulangi hal tersebut diperlukan suatu pencegahan. Pencegahan fouling memerlukan biaya yang sangat besar seperti yang dilaporkan oleh [2] dimana pemerintah dan industri di Amerika setidaknya menghabiskan 6,5 juta dollar.

Pencegahan fouling yang dilakukan adalah melapisi kapal dan bangunan yang terendam dengan cat antifouling. Cat antifouling komersial mengandung senyawa yang mampu menghambat organisme fouling untuk menempel, senyawa tersebut adalah tributyltin organotin ${ }^{1}$. Tributyltin organotin (TBT) bekerja dengan membunuh foulers maupun organisme lain yang menempel.
Tidak hanya menyebabkan kematian tetapi TBT mengakibatkan imposex pada organisme. Imposex merupakan peristiwa berubahnya kelamin dimana organisme betina akan berubah menjadi jantan dan organisme jantan menjadi steril [3][4]

TBT terbukti ampuh untuk mencegah fouling namun tidak ramah bagi lingkungan. Tahun 2008 TBT resmi dilarang oleh International Maritime Organization. Pelarangan penggunaan TBT tidak sesuai dengan penemuan di lapang. Di Manado masih ditemukan pencemaran TBT pada sedimen sebesar $250 \mathrm{ug} / \mathrm{kg} \mathrm{dw} ; 4,25 \mathrm{ug} / \mathrm{g}$ ww, lebih tinggi 45 kali lipat dibandingkan Jepang ${ }^{2}$.

Larangan penggunaan TBT menjadi tantangan untuk mencari alternatif ketersediaan antifouling ramah lingkungan. Beberapa Marine Natural Produk seperti mangrove diketahui memiliki potensi antifouling [5][6][7]

. Bagian dari mangrove yang bisa digunakan sebagai antifouling adalah daun. Daun pada mangrove diduga memiliki metabolit sekunder yang lebih banyak dibandingkan dengan jaringan

* Corresponding Author.Tel: +6281235809421

E-mail: alfincahyaningtyas@gmail.com 
lain. Hal tersebut sesuai dengan pernyataan [7]dimana daun merupakan tempat fotosintesis berlangsung, hasil dari proses fotosintesis (gula, karbohidrat) akan digunakan untuk pembentukan metabolit sekunder. Sehingga pada penelitian ini jaringan mangrove yang digunakan adalah daun.

Penelitian mengenai potensi mangrove Avicennia marina sebagai antifouling sudah pernah dilakukan sebelumnya dengan organisme uji bakteri (microfouling). Oleh karena itu pada penelitian ini pengujian antifouling mangrove Avicennia marina menggunakan organisme uji kerang hijau (macrofouling), yang tergolong dalam kategori hard fouling .

\section{Materi dan Metode}

\subsection{Mangrove}

Pada penelitian ini, mangrove dibersihkan dari epifit serta kotoran yang menempel. Daun mangrove Avicennia marina diperoleh dari Pantai Lekok, Pasuruan.

\subsection{Ekstraksi Avicennia marina}

Daun Avicennia marina yang diperoleh dicuci menggunakan air laut untuk menghilangkan kotoran. Selanjutnya dikeringkan dengan cara diangin-anginkan selama empat minggu, kemudiian dihaluskan menggunakan blender. Sebanyak 200 gram tepung mangrove dimaserasi menggunakan pelarut metanol $600 \mathrm{ml}$ (1:3) selama 72 jam pada suhu ruang. Mangrove yang telah dimaserasi disaring menggunakan kertas Whatman no. 1. Ekstrak mangrove kemudian di evaporasi menggunakan Rotary evaporator. Hasil ekstrak kemudian disimpan pada botol vial dengan suhu $4^{0} \mathrm{C}$.

\subsection{Sampel Organisme}

Sampel organisme macrofouler yang digunakan adalah Perna viridis dengan panjang \pm $1.5-2 \mathrm{~cm}$. Hewan uji diperoleh dari pengepul desa Panggung rejo, Pasuruan.

\subsection{Aklimatisasi}

Proses awal sebelum dilakukan uji antifouling adalah aklimatisasi selama tujuh hari. Hewan yang diperoleh dibersihkan dari kotoran dan dilakuan pemotongan byssus terlebih dahulu, kemudian dimasukkan ke dalam wadah aklimatisasi (akuarium). Selama proses ini kerang hijau diberi pakan Chlorella sp.

\subsection{Pengujian Antifouling Avicennia marina Terhadap Perna viridis}

Rancangan penelitian yang digunakan adalah Rancangan Acak Lengkap dengan mengacu pada metode penelitian terdahulu ${ }^{[19]}$. Metode yang digunakan adalah metode anti penempelan / pelekatan. Metode ini dipilih karena lebih cepat dalam mendapatkan hasil. Proses pengujian diawali dengan mempersiapkan beaker glass 500 $\mathrm{ml}$ yang telah diisi air laut yang mengandung 3 $\mathrm{ml}$ ekstrak A. marina. Perna viridis yang telah diaklimatisasi dipindahkan ke dalam beaker glass yang berbeda. Jumlah Perna viridis yang digunakan adalah 5 ekor untuk tiap beaker glass. Pengujian dilakukan dengan tiga kali ulangan untuk setiap konsentrasi. Konsentrasi yang digunakan adalah 1, 2, 4, 6, dan $8 \mathrm{mg} / \mathrm{ml}$. Pengamatan Perna viridis dilakukan 1x24 jam dan 2x24 setelah pemaparan. Hewan uji yang berusaha melekat pada kawanannya dipisahkan menggunakan spatula.

\subsection{Analisa Statistik}

Data pengamatan yang diperoleh dianalisa menggunakan software SPSS versi 16.0. Analisa yang dilakukan adalah uji normalitas dan ANOVA.

\section{HASIL DAN PEMBAHASAN}

\subsection{Ekstrak Mangrove Avicennia marina}

Tepung mangrove sebanyak 200 gr yang telah direndam menggunakan pelarut menghasilkan 10.55 gr ekstrak. Jumlah ekstrak yang didapatkan pada penelitian ini lebih besar bila dibandingkan dengan penelitian sebelumnya [8]yang juga menggunakan A. marina serta metanol sebagai pelarut. Pada penelitian tersebut ekstrak A. marina yang dihasilkan adalah 5.95 gr. Perbedaan jumlah ekstrak yang dihasilkan dipengaruhi oleh jumlah daun yang digunakan serta waktu perendaman. Perbedaan hasil ekstrak yang dihasilkan dapat dilihat pada Tabel 1.

Tabel 1.

Perbedaan Hasil Ekstrak Avicennia marina

\begin{tabular}{cccc}
\hline $\begin{array}{c}\text { Jumlah } \\
\text { Daun } \\
(\mathrm{gr})\end{array}$ & $\begin{array}{c}\text { Waktu } \\
\text { Perendaman } \\
\text { (jam) }\end{array}$ & $\begin{array}{c}\text { Ekstrak } \\
\text { yang } \\
\text { dihasilkan } \\
\text { (gr) }\end{array}$ & $\begin{array}{c}\text { Randemen } \\
\text { ekstrak (\%) }\end{array}$ \\
\hline $200 \mathrm{gr}$ & 72 jam & 10.55 & 5.27 \\
$150 \mathrm{gr}$ & 26 jam & 5.95 & $3.96^{*}$ \\
\hline
\end{tabular}

Keterangan: * Hasil Penelitian Terdahulu[8]

\subsection{Hasil Uji Antifouling Perna viridis}

Uji antifouling terhadap Perna viridis dilakukan secara in vitro dengan pengamatan $1 \mathrm{x}$ 24 jam dan $2 \times 24$ jam. Pengamatan yang dilakukan adalah pengamatan visual terhadap byssus dan pelekatan Perna viridis. Penghambatan ekstrak mangrove terhadap Perna viridis dicatat pada tabel skoring. Penilaian yang dicatat adalah 1) Perna viridis yang melekat; 2) 
Perna viridis yang tidak melekat; 3) Perna viridis yang mati. Jumlah byssus Perna viridis yang terbentuk dapat dilihat pada Tabel 2.

Tabel 2.

Jumlah Rata-rata Perna viridis yang Tidak Melekat dan Jumlah byssus yang Terbentuk

\begin{tabular}{|c|c|c|c|c|}
\hline \multirow{2}{*}{$\begin{array}{l}\mathrm{N} \\
\mathrm{O}\end{array}$} & \multirow{2}{*}{$\begin{array}{c}\text { Konsentr } \\
\text { asi } \\
(\mathrm{mg} / \mathrm{ml})\end{array}$} & \multicolumn{2}{|c|}{$\begin{array}{l}\text { Pengamatan } \\
\text { (individu) }\end{array}$} & \multirow{2}{*}{$\begin{array}{c}\text { Byssus } \\
\text { yang } \\
\text { Terbentu } \\
\text { k }\end{array}$} \\
\hline & & $\begin{array}{l}1 \times 24 \\
\text { jam }\end{array}$ & $\begin{array}{l}2 \times 24 \\
\text { jam }\end{array}$ & \\
\hline 1 & 1 & 2 & 2 & $\begin{array}{l}15-25 \\
\text { helai }\end{array}$ \\
\hline 2 & 2 & 1 & 1 & $\begin{array}{c}10- \\
15 \text { helai }\end{array}$ \\
\hline 3 & 4 & 0 & 0 & $\begin{array}{l}15-25 \\
\text { helai }\end{array}$ \\
\hline 4 & 6 & 1 & 1 & $\begin{array}{l}15-20 \\
\text { helai }\end{array}$ \\
\hline 5 & 8 & 1 & 2 & $\begin{array}{l}10-20 \\
\text { helai }\end{array}$ \\
\hline
\end{tabular}

Berdasarkan tabel pengamatan 1x24 jam menunjukkan penghambatan Perna viridis ratarata pada konsentrasi $1 \mathrm{mg} / \mathrm{ml}$ adalah 1 ekor. Pada konsentrasi $2 \mathrm{mg} / \mathrm{ml} 1$ ekor. Konsentrasi 4 $\mathrm{mg} / \mathrm{ml}$ tidak menunjukkan penghambatan karena seluruh kerang melekat. Rata-rata penghambatan konsentrasi $6 \mathrm{mg} / \mathrm{ml}$ dan $8 \mathrm{mg} / \mathrm{ml}$ adalah 1 ekor.

Respon yang nampak pada Perna viridis yang tidak melekat pada tiap konsentrasi adalah berada di dasar beaker glass. Pada konsentrasi tertinggi yaitu $8 \mathrm{mg} / \mathrm{ml}$ Perna viridis yang tidak melekat menutup rapat cangkang dan berada di dasar. Pengamatan dilanjutkan sampai 2x24 jam untuk melihat penghambatan ekstrak lebih lanjut. Pada waktu $2 \times 24$ jam jumlah Perna viridis yang tidak melekat sama dengan pengamatan 1x24 jam kecuali pada konsentrasi $8 \mathrm{mg} / \mathrm{ml}$. Hewan uji yang mati segera diambil dan tidak terdapat penggantian hewan uji yang baru.

Peningkatan konsentrasi ekstrak memberikan pengaruh pada pembentukan byssus (Tabel 2). Hal ini ditunjukkan dengan jumlah byssus yang kurang dari 50 helai. Byssus normal memiliki jumlah benang 50-100. Pembentukan byssus diawali dengan satu buah benang di bagian perut ventral dalam waktu 5 menit. Jumlah benang byssus juga menjadi faktor ketahanan kerang dalam melekat. Kekuatan dari byssal threads dipengaruhi oleh beberapa faktor antara lain musim, waktu pemijahan, epifit, dan keberadaan predator [9]

Berdasarkan penelitian ini mengindikasikan bahwa Perna viridis terganggu dengan penambahan ekstrak Avicennia marina. Pada konsentrasi $1 \mathrm{mg} / \mathrm{ml}$ byssus yang terbentuk berkisar antara 15 - 25 helai dengan karakteristik panjang dan tebal. Produksi byssus pada konsentrasi $2 \mathrm{mg} / \mathrm{ml}$ yang bisa diamati adalah 10 - 15 helai dengan karakteristik hampir sama pada konsentrasi $1 \mathrm{mg} / \mathrm{ml}$ Gambar 1 .
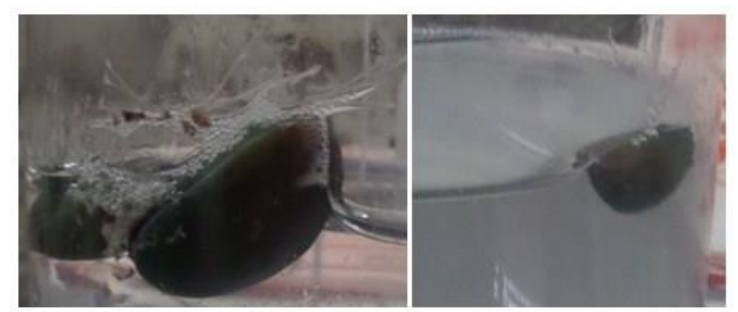

Gambar 1. Produksi byssus pada konsentrasi $1 \mathrm{mg} / \mathrm{ml}$ (kiri) dan konsentrasi $2 \mathrm{mg} / \mathrm{ml}$ (kanan)

Pada konsentrasi $4 \mathrm{mg} / \mathrm{ml}$ jumlah byssus berkisar antara 15 - 25 helai dengan karakteristik byssus lebih pendek dan lebih tipis. Konsentrasi 6 $\mathrm{mg} / \mathrm{ml}$ menunjukkan produski byssus antara 15 20 helai dengan karakteristik byssus pendek dan tipis. Konsentrasi $8 \mathrm{mg} / \mathrm{ml}$ produksi byssus adalah 10 - 20 helai dengan karakteristik byssus sangat tipis (Gambar 2). Karakteristik bentuk byssus menunjukkan bahwa Perna viridis terganggu hal ini sesuai dengan pernyataan [10]dimana bentuk byssus tipis bisa diakibatkan oksigen terlarut pada perairan sangat sedikit (hypoxia).

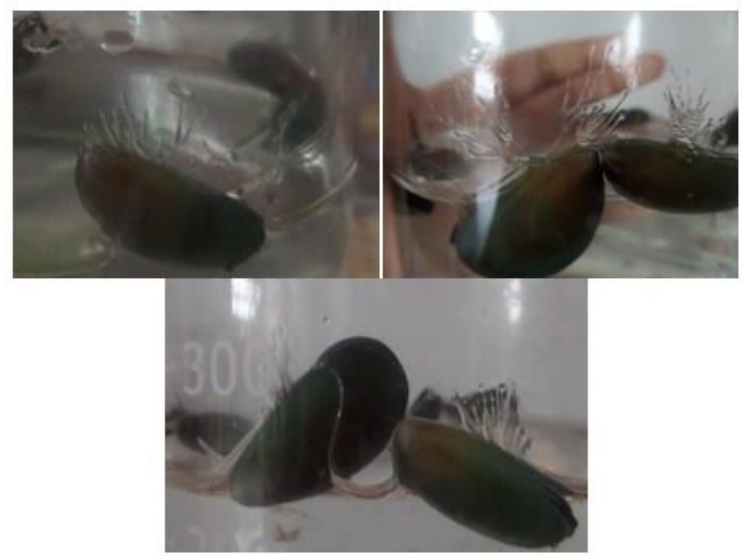

Gambar 2. Produksi byssus pada konsentrasi $4 \mathrm{mg} / \mathrm{ml}$ (kiri), konsentrasi $6 \mathrm{mg} / \mathrm{ml}$ (kanan), konsentrasi $8 \mathrm{mg} / \mathrm{ml}$ (bawah)

Gangguan produksi byssus kemungkinan akibat Avicennia marina karena semua parameter sudah sesuai dengan yang dibutuhkan Perna viridis. Diduga komponen aktif yang ada pada Avicennia marina inilah yang menggagu pelekatan Perna viridis. Komponen aktif tersebut adalah alkohol dan fenol, dua komponen ini berpotensi sebagai biofoulant [7]. Parameter yang mempengaruhi produksi byssus antara lain salinitas dan oksigen terlarut. Berdasarkan penelitian ${ }^{[7]}$ produksi byssus berkurang bahkan berhenti pada saat keadaan lingkungan menjadi 
miskin oksigen dan salinitas rendah. Kisaran salinitas yang optimum untuk pembentukan byssus adalah 20.7 - 35.4 ppm [11]. Pada penelitian ini nilai salinitas dan oksigen terlarut masih dalam kondisi yang sesuai.

\subsection{Analisa Data}

Berdasarkan uji normalitas diketahui bahwa sebaran data hasil pengamatan 1x24 jam dan $2 \times 24$ jam memiliki distribusi yang normal. Hal ini ditunjukkan dengan nilai signifikan 0.299 pada pengamatan $1 \times 24$ jam dan 0.409 pada $2 \times 24$ jam yang mana nilai tersebut lebih dari 0.05 . Analisa data dilanjutkan ke sidik ragam (ANOVA).

Uji sidik ragam digunakan untuk mengetahui pengaruh ekstrak mangrove Avicennia marina terhadap pelekatan Perna viridis. Pengujian ANOVA menggunakan software SPSS 16.0.

Berdasarkan hasil sidik ragam diketahui nilai signifikan adalah 0.323. Menurut [12]jika nilai signifikan lebih dari 0.05 maka terima H0. H0 merupakan hipotesis yang menyatakan tidak ada perbedaan antara dua variabel, atau tidak adanya pengaruh variabel $\mathrm{X}$ terhadap $\mathrm{Y}$. Pada penelitian ini seharusnya $\mathrm{HO}$ ditolak atau terima $\mathrm{H} 1$, namun hasil yang didapat adalah $\mathrm{HO}$ diterima. Hal ini bukan berarti penelitian ini salah atau tidak memiliki hubungan. Faktor yang dapat mempengaruhi hasil pengujian hipotesis adalah kurangnya sampel maupun variabel dalam penelitian. Variabel yang ada penelitian ini adalah konsentrasi yang digunakan.

\subsection{Pembahasan}

Hasil sidik ragam menunjukkan bahwa pemberian ekstrak Avicennia marina tidak berpengaruh nyata terhadap penghambatan Perna viridis. Faktor yang dapat mempengaruhi hasil tersebut antara lain adalah ekstrak mangrove, jumlah konsentrasi, habitat serta jenis hewan uji.

Pada penelitian [5] Avicennia marina terbukti mampu menghambat Patella vulgata pada konsentrasi $6 \mathrm{mg} / \mathrm{ml}$. Konsentrasi tersebut merupakan konsentrasi yang aman dalam menghambat penempelan Patella vulgata. Avicennia marina menjadi toksik pada konsentrasi $10 \mathrm{mg} / \mathrm{ml}$.

Penelitian lain oleh [13]menunjukkan konsentrasi yang efektif menghambat Perna viridis adalah $0.2 \mathrm{mg} / \mathrm{ml}$ untuk ekstrak yang berasal dari sponge A. pfeifferae dan A. turgida. Pada tahun 2002 [3]juga melakukan penelitian antifouling terhadap Perna indica. Hasil penelitian menunjukkan konsentrasi yang efektif untuk menghambat Perna indica adalah 0.05 $\mathrm{mg} / \mathrm{ml}$. Ekstrak yang digunakan berasal dari
Distaplia nathensis. [1] menunjukkan konsentrasi yang efektif untuk menghambat Perna indica adalah $0.022 \mathrm{mg} / \mathrm{ml}$. Ekstrak yang digunakan pada penelitian tersebut adalah lamun Syringodium isoetifolium. Pada penelitian ini konsentrasi yang digunakan adalah 1, 2, 4, 6, dan $8 \mathrm{mg} / \mathrm{ml}$. Konsentrasi ini diharapkan mampu menunjukkan efektivitas penghambatan Avicennia marina terhadap Perna viridis. Adanya perbedaan hasil penelitian ini dengan penelitian lain diduga disebabkan jenis hewan uji dan bahan ekstrak yang diujikan berbeda.

Hewan uji diperoleh dari perairan Pasuruan tepatnya pada Pantai Semare yang berdekatan dengan Pelabuhan Pasuruan. Pelabuhan Pasuruan menjadi tempat keluar masuk kapal baik kapal dagang atau kapal perikanan. Keberadaan pelabuhan yang berdekatan dengan sungai dan pemukiman penduduk mengakibatkan masukan limbah. Limbah tersebut antara lain limbah domestik dan logam berat. Logam berat yang ditemukan di perairan Pelabuhan Pasuruan adalah $\mathrm{Cu}$ dan $\mathrm{Cd}$. Konsentrasi $\mathrm{Cu}$ di perairan Pelabuhan Pasuruan berkisar $0.0156-0.102 \mathrm{mg} / \mathrm{ml}$ sedangkan di sedimen berkisar $0.0901-0.3942$ $\mathrm{mg} / \mathrm{ml}$. Konsentrasi $\mathrm{Cd}$ yang ditemukan pada perairan dan sedimen adalah $0.0271-0.0675$ $\mathrm{mg} / \mathrm{ml}$ dan $0.0343-0.1002 \mathrm{mg} / \mathrm{ml}$ [14]

Tingginya nilai $\mathrm{Cu}$ dan $\mathrm{Cd}$ akan memberikan pengaruh terhadap biota sekitar termasuk Perna viridis. Perna viridis merupakan bivalvia yang hidup sesil pada substrat [15]. Keadaan ini menjadikan kerang tidak dapat berpindah secara cepat ketika terjadi sutu pencemaran termasuk pencemaran logam berat. Paparan logam berat yang berasal dari lingkungan akan masuk ke dalam tubuh Perna viridis. Logam berat yang masuk kemudian akan diakumulasikan ke dalam tubuh. Keadaan Perna viridis yang selalu terpapar terhadap bahan pencemar menjadikannya kebal (resisten). Kondisi ini diduga dapat menyebabkan pemberian ekstrak Avicennia marina sebagai antifouling tidak memberikan pengaruh nyata terhadap pelekatan kerang hijau.

\subsection{Perbandingan Penelitian Terdahulu}

Penelitian potensi Avicennia marina sebagai antifouling sudah pernah dilakukan oleh [16]. Pada penelitian tersebut target atau organisme yang diuji adalah bakteri dan diatom, yang mana tergolong dalam kategori microfouling. Perbedaan penelitian ini dengan penelitian sebelumnya adalah penggunaan hewan uji yaitu Perna viridis. Sehingga penelitian ini berfokus pada potensi Avicennia marina terhadap macrofouler Perna viridis 


\section{Kesimpulan}

Berdasarkan hasil penelitian didapatkan hasil bahwa ekstrak Avicennia marina tidak memberikan pengaruh yang nyata terhadap pelekatan Perna viridis. Hal ini diduga toleransi Perna viridis terhadap suatu senyawa yang masuk ke dalam tubuhnya sangat tinggi. Akan tetapi bila dilihat dari produksi byssus maka dapat dikatakan bahwa Avicennia marina menghambat produksi byssus Perna viridis. Jumlah byssusPerna viridis kurang dari 50 helai bila dibandingkan dengan kondisi normal.

\section{UCAPAN TERIMAKASIH}

Terimakasih penulis ucapkan pada temanteman serta semua pihak yang telah membantu dalam proses penelitian.

\section{REFERENSI}

[1] P. Iyapparaj et al., "Antifouling and toxic properties of the bioactive metabolites from the seagrasses Syringodium isoetifolium and Cymodocea serrulata," Ecotoxicol. Environ. Saf., vol. 103, hal. 54-60, Mei 2014

[2] Bhadhury, P and Wright P.C, "Exploitation of Marine Algae : Biogenic Compounds for Potential Antifouling Applications," Planta, vol. 219, no. 4, hal. 561-578, 2004.

[3] R. Murugan, A, "Biofouling deterrent activity of the natural product from ascidian, Distaplia nathensis [Chordata]," CSIR, vol. 32, hal. 162-164, Jun 2003.

[4] Puspitasari, Rachma, "Evaluasi Penggunaan Ekstrak Lamun Sebagai Bahan Aktif Antifouling Terhadap Produsen Perairan," Segara, vol. 12, no. 1, hal. 316322, 2016.

[5] A. Manilal, S. Sujith, G. S. Kiran, J. Selvin, dan C. Shakir, "Biopotentials of mangroves collected from the southwest coast of India," J. Biotechnol. Biochem., vol. 4, no. 1, hal. 59-65, 2009.

[6] S. Nandhini dan K. Revathi, "Antifouling Activity of Extracts from Mangroves against Biofouling Bacteria Isolated from Boats in Royapuram, Chennai, India," Int. J. Curr. Microbiol. Appl. Sci., vol. 5, no. 8, hal. 324-335, Agu 2016.

[7] S. Prabhakaran, R. Rajaram, V. Balasubramanian, dan K. Mathivanan, "Antifouling potentials of extracts from seaweeds, seagrasses and mangroves against primary biofilm forming bacteria," Asian Pac. J. Trop. Biomed., vol. 2, no. 1, hal. S316-S322, Jan 2012.

[8] R. H. Danada dan A. Yamindago, "Analisis aktivitas antibakteri ekstrak daun mangrove Avicennia marina dari Kabupaten Trenggalek dan Kabupaten Pasuruan terhadap pertumbuhan Staphylococcus aureus dan Vibrio alginolyticus," J. Kelaut. Indones. J. Mar. Sci. Technol., vol. 7, no. 1, hal. 12-19, 2014.

[9] J. H. Waite dan C. C. Broomell, "Changing environments and structure-property relationships in marine biomaterials," $J$. Exp. Biol., vol. 215, no. 6, hal. 873-883, Mar 2012.

[10] Y. Wang, M. Hu, S. G. Cheung, P. K. S. Shin, W. Lu, dan J. Li, "Antipredatory responses of Perna viridis (Linnaeus, 1758) under acute hypoxia and low salinity," $J$. Molluscan Stud., vol. 79, no. 1, hal. 42-50, Feb 2013.

[11] Vakily, J.M, The Biology and Culture of Mussels of The Genus Perna. Federal Republic Of Germany, 1989.

[12] Adji Sastrosupadi, "Rancangan Percobaan Praktis Bidang Pertanian," in Rancangan Percobaan Praktis Bidang Pertanian, Revisi., Yogyakarta: Kanisius, 2000.

[13] W. A. Wilsand,V B. dan Bapuji,M, "Antifouling activities of marine sedentary invertebrates on some macrofoulers," Indian J. Mar. Scince, vol. 28, hal. 280284, 2009.

[14] Aminah, S Defri,Y, "Sebaran Konsentrasi Logam Berat $\mathrm{Cu}$ (Tembaga) dan $\mathrm{Cd}$ (Kadmium) Pada Air dan Sedimen Di Perairan Pelabuhan Pasuruan, Jawa Timur," dipresentasikan pada Seminar Nasional Perikanan dan Ilmu Kelautan IV, Fakultas Perikanan dan Ilmu Kelautan Universitas Brwaijaya Malang, Malang, 2016, hal. 415-421.

[15] H.A.W. Cappenberg, "Beberapa Aspek Biologi Kerang Hijau," Oseana, vol. 33, hal. 33-40, 2008.

[16] S. Deepa, M. Srikumar, dan K. Padmakumar, "International Journal of Natural Products Research," 2014. 